Med. thorac. 1962;19:1-3

\title{
Vorwort - Preface - Préface
}

Die Forschung auf dem Gebiet der Pathophysiologie, Klinik und Therapie der Thoraxorgane hat in den beiden letzten Jahrzehnten eine außerordentliche Ausweitung erfahren. Der intensive Ausbau der Chemotherapie bakterieller Infektionen verbesserte die Prognose infektiöser Lungenund Herzkrankheiten entscheidend. Zusammen mit der modernen Narkosetechnik eröffnete sie den Weg zur chirurgischen Behandlung aller Thoraxorgane. Herz- und Lungenphysio-logie werden praktisch angewandt und sind durch den Ausbau respiratorischer und zirkulatorischer Funktionsprüfungen zu unentbehrlichen diagnostischen Hilfsmitteln in der Klinik geworden. Im Rahmen dieses Geschehens hat sich das Erscheinungsbild der Thorax-krankheiten und die Häufigkeit ihres Auftretens stark gewandelt. Manche Affek-tionen sind zurückgegangen, andere sind in den Vordergrund getreten. So haben moderne Hygiene, Chemotherapie und chirurgische Technik die Tuberkulose in zahlreichen Ländern zurückgedrängt. Dagegen sind andere Krankheiten wie chronische Bronchitis, Lungenemphysem, Bronchialcarcinom an ihre Stelle gerückt.

Im Sinne dieser Entwicklung liegt es, wenn die «Schweizerische Zeitschrift für Tuberkulose und Pneumonologie» nun in «Medicina Thoracalis» mit entspre-chend erweitertem Programm umgestaltet wird.

Umfang und Kompliziertheit der Forschung auf dem weitläufigen Feld der Thoraxmedizin erfordern heute enge Zusammenarbeit auf internationaler Basis. Aktuelle und wesentliche Beiträge aus dem gesamten Arbeitsgebiet zu vermitteln, ist die Aufgabe von «Medicina Thoracalis ». Zu ihrer Verwirklichung hat sich ein internationales Redaktionskomitee von Klinikern, Physiologen, Pathologen und Mikrobiologen zusammengefunden. Ihre koordinierten Bestrebungen werden zeigen, daß Spezialisierung nicht gleichzusetzen ist mit einer Einengung des Blick-feldes. Aus der Zusammenarbeit vieler Spezialisten wird sich die Möglichkeit eines Gesamtüberblickes ergeben, ohne daß die Qualität des Spezialfaches darunter zu leiden hat. Schriftleitung und Verlag ist es ein Anliegen, an dieser Stelle alien Mitarbei-tern zu danken, welche die «Schweizerische Zeitschrift für Tuberkulose und Pneumonologie » zu einem geachteten und weitverbreiteten Publikationsorgan gemacht haben, ganz besonders Herrn Prof. E. Uehlinger, der als Mitbegründer die Leitung der Zeitschrift nach dem Tode von Dr. E. Bachmann übernommen hat. «Medi-cina Thoracalis» wird eine bereits vorgezeichnete Aufgabe übernehmen und er-weitern. Beratern und Mitarbeitern, die durch ihren tatkräftigen Einsatz zum Gelingen dieses Vorhabens beitragen, wissen wir uns in hohem Maße verpflichtet.

Basel, den 15. August 1962 H.Herzog

Med. thorac. Vol. 19, No. 1 (1962)

1

PREFACE

Research in the fields of pathophysiology, clinical aspects and treatment of the thoracic organs has undergone an extraordinary expansion in the last two decades. The intensive development of chemotherapy for bacterial infections has brought a decisive improvement in the prognosis of pulmonary and cardiac infections. This, together with modern anesthetic techniques, has made 
all the thoracic organs accessible to surgery. Knowledge of the physiology of the heart and lungs is put to practical use, an increasing range of tests of respiratory and circulatory function having become indispensible clinical tools of diagnosis.

In this process, the nature and incidence of thoracic diseases have changed profoundly. Some conditions have diminished, others have come into prominence. Modern methods of hygiene, chemotherapy and surgery have checked tuberculosis, but other illnesses, like chronic bronchitis, pulmonary emphysema and bronchial carcinoma have taken its place.

It is in line with this development for the "Schweizerische Zeitschrift für Tu-berkulose und Pneumonologie" now to be transformed into "Medicina Thoracalis" and to undertake a correspondingly extended program.

The range and complexity of research today in the far-reaching field of thoracic medicine make close international cooperation essential. The task of "Medicina Thoracalis" will be to present significant and up-to-date contributions from the whole of this field. For this purpose, an international editorial committee comprising physicians, physiologists, pathologists and microbiologists, has been formed. Their coordinated efforts will show that specialization need not be synonymous with limiting the breadth of vision. This cooperation between many specialists will ensure the possibility of an overall view, without the quality of the individual specialty suffering thereby.

At this point, the Editors and Publishers wish to thank all those who have helped to make the "Schweizerische Zeitschrift für Tuberkulose und Pneumonologie" a widely-read and respected organ of publication, and especially Professor E. Uehlinger who, as co-founder of the journal, took over the editorship on the death of Dr. E.Bachmann. "Medicina Thoracalis" will be assuming and expanding a role which has already been delineated. We are conscious of our great debt to all those who will be giving us their willing help and advice in the successful performance of this task.

Basel, August 15,1962

H. Herzog

PREFACE

Les vingt dernières années nous ont permis d'assister au développement considerable de la recherche scientinque en matière de pathophysiologie, de clinique et de thérapeutique d'affections des organes thoraciques. Les rapides progrès dans le domaine de la chimiothérapie des infections bactériennes d'une part ont nettement amélioré le pronostic des maladies infectieuses pulmonaires et cardiaques; la chimiothérapie a ouvert d'autre part la route aux interventions chirurgicales sur les organes endothoraciques. On a vu naître l'application pratique de la physiologie cardio-pulmonaire, dont les méthodes particulières sont devenues aujourd'hui des complements indispensables pour le diagnostic clinique.

Dans le cadre de cette evolution, l'aspect des maladies des organes du thorax et la frequence de leur apparition se sont Fun et l'autre considérablement modifies. Plusieurs maladies sont en regression, d'autres semblent jouer actuellement unplus grand role qu'autrefois. C'est ainsi que dans bien des pays, grace à une meilleure hygiene générale, à la chimiothérapie et aux progrès de la technique chirurgicale, la tuberculose pulmonaire n'est plus au premier plan; elle semble avoir laissé la place à d'autres affections broncho-pulmonaires comme la bronchite chronique, l'emphysème et le cancer bronchique.

II est done naturel qu'un périodique tel que la «Revue Suisse de la Tuberculose et de Pneumonologie» élargisse sensiblement son programme en consideration des tendances 
actuelles, et c'est la raison pour laquelle nous avons modifié le titre de cette revue et choisi «Medicina Thoracalis».

Dans le vaste domaine de la médecine du thorax la recherche fait de rapides progrès, elle est devenue compliquée et exige avant tout une collaboration étroite sur le plan international.

Comme «Medicina Thoracalis» se propose de publier des travaux modernes touchant à tous les domaines des affections thoraciques, nous avons fait appel à un comité de redaction international, groupant des cliniciens, des physiologistes, des pathologistes et des microbiologistes; la coordination de leurs efforts montrera qu'une specialisation n’équivaut pas à un rétrécissement du champ d'action; la collaboration entre spécialistes doit aboutir au contraire à une vue d'ensemble sans que la spécialité perde pour cella de sa valeur.

Rédacteurs et editeurs profitent de l'occasion qui s'offre pour remercier tous les anciens collaborateurs de la « Revue Suisse de la Tuberculose et de Pneumonologie » grace auxquels ce périodique est devenu un organe de publication fort en vue; ils remercient plus particulièrement M. le Professeur E. Uehlinger qui en dirigea la redaction après la mort du Docteur E. Bachmann. «Medicina Thoracalis » poursuivra une voie précédemment ouverte,elle élargirale champ d'action indiqué. Nous sommes reconnaissants à tous ceux qui nous ont conseillé et à tous nos collaborateurs qui contribueront de près ou de loin à réaliser le programme que nous nous sommes propose.

Bale, le 15 août 1962

H. Herzog 